\title{
PENGEMBANGAN PROSEDUR SISTEM PERKULIAHAN ONLINE YANG EFEKTIF DALAM MENINGKATKAN MINAT BELAJAR MAHASISWA SEKOLAH TINGGI TEOLOGI KRISTUS ALFA OMEGA SEMARANG
}

\author{
Jon \\ (Dosen S1 Pendidikan Agama Kristen STT Kristus Alfa Omega: bongminj@yahoo.com)
}

\begin{abstract}
Research on the Development of Online Lecture Systems which is effective in increasing the learning interest of Sekolah Tinggi Teologi Kristus Alfa Omega students aims to describe the Development of the Online Lecture System into a valid, practical and effective product. The method used in this research is Research and Development with the ADDIE model (Analysis, Design, Development, Implementation, and Evaluation). Based on the results of the research that has been done, the Online Lecture System which is effective in increasing student interest in learning is valid for use in Sekolah Tinggi Teologi Kristus Alfa Omega, according to the results of the assessment of two expert teams, namely Waket 1 and Dir. Postgraduate Sekolah Tinggi Teologi Kristus Alfa Omega Semarang with 100 percentages each and the results of student responses were good, namely with a percentage of $81.4 \%$ and $81.2 \%$.
\end{abstract}

Keywords: Online Lecture System, Student Learning Interest

\section{A. PENDAHULUAN}

Sejak Pandemi Covid 19, Pemerintah Indonesia melalui Kementerian Pendidikan dan Kebudayaan dan Kementerian Agama RI, menerapkan kebijakan belajar dan bekerja dari rumah (Work from Home) mulai pertengahan Maret 2020. Sekolah Tinggi Teologi Kristus Alfa Omega sebagai salah satu Perguruan Tinggi Keagamaan Kristen (PTKK) yang berada di bawah Kementerian Agama, merespon penerapan belajar dan bekerja dari rumah (WFH) ini dengan menerbitkan (mengeluarkan) Surat Edaran Nomor 048/STT-

KAO/KETUA/IV/2020 pada tanggal 16 April 2020. Salah satu isi dalam surat edaran tersebut adalah himbauan untuk pelaksanaan kegiatan belajar mengajar dalam bentuk jarak jauh atau online. Perubahan proses pembelajaran online (daring) yang dilakukan secara serentak oleh semua dosen dan mahasiswa ini, menyebabkan dosen harus menentukan format, mekanisme, bentuk dan alat pembelajaran yang tepat serta sesuai dengan kondisi mahasiswa.

Hasil keputusan rapat pimpinan Sekolah Tinggi Teologi Kristus Alfa Omega pada hari Selasa, 15 April 2020 telah mengeluarkan ketentuan Pembelajaran dari rumah atau jarak jauh. Dalam ketentuan pembelajaran jarak jauh ini tidak sedikit dosen dan mahasiswa yang mengalami kendala atau hambatan yaitu salah satunya dengan sistem perkuliahan online yang digunakan. Selain itu, masalah yang lain adalah tidak terbiasanya dosen dan mahasiswa melaksanakan proses belajar mengajar secara online karena hal ini baru pertama kali dilakukan semenjak Pandemi Coronavirus Disease 2019 (Covid 19). 
Jaringan internet yang dipakai baik oleh dosen dan mahasiswa juga menjadi kendala karena perkuliahan online sangat tergantung dengan kecepatan internet atau kekuatan sinyal masing-masing pengguna. Beberapa dosen yang mengajar secara online juga mengeluhkan bahwa terdapat beberapa mahasiswa yang tidak secara serius mengikuti proses belajar mengajar selama perkuliahan online dilaksanakan. Ada kendala, yaitu keluhan dari beberapa mahasiswa yang menganggap perkuliahan secara online ini kurang maksimal karena banyak materi yang disampaikan secara cepat dan terbatasnya diskusi atau tanya jawab yang dapat dilakukan. Berdasarkan beberapa fakta-fakta yang telah diuraikan di atas, peneliti melakukan penelitian dan pengembangan yang berjudul "Pengembangan Sistem Perkuliahan Online yang Efektif dalam Meningkatkan Minat Belajar Mahasiswa Sekolah Tinggi Teologi Kristus Alfa Omega Semarang."

Peningkatan kualitas lulusan merupakan tujuan utama proses pendidikan, sebab keberhasilan proses pendidikan terlihat dari kecakapan lulusan dalam menjadwab kebutuhan pengguna lulusan. ${ }^{1}$ STT KAO sudah membuat sistem perkuliahan online berupa prosedur. Tetapi di dalam Prosedur tersebut masih terdapat beberapa kekurangan dan perlu ditambahkan lagi agar menjadi lebih jelas. Adapun kekurangan dari sistem perkuliahan online yang lama antara lain yaitu tidak adanya penggunaan aplikasi secara khusus yang harus digunakan oleh dosen dalam mengajar perkuliahan online sehingga setiap dosen mengajar dengan menggunakan aplikasi yang dirasanya nyaman, bahkan ada dosen yang mengajar hanya dengan share materi ke mahasiswa dan diskusi lewat WA saja. Penggunaan aplikasi berupa video conference oleh beberapa dosen juga tidak dibatasi waktunya sehingga banyak mahasiswa yang mengeluhkan pemakaian kuota yang cukup besar. Selain itu, sistem perkuliahan online yang berupa prosedur tersebut dinilai terlalu sederhana sehingga tidak memberikan kejelasan yang mendetail dalam melaksanakan perkuliahan online. Oleh karena itu, peneliti tertarik untuk mengembangkan prosedur atau sistem perkuliahan online STT KAO.

\section{E-learning}

E-learning adalah pembelajaran yang disusun dengan tujuan menggunakan sistem elektronik atau komputer sehingga mampu mendukung proses pembelajaran. ${ }^{2}$ Selain itu, E-Learning juga diartikan sebagai proses pembelajaran jarak jauh dengan cara menggabungkan prinsip-prinsip dalam proses pembelajaran dengan teknologi. ${ }^{3}$ E-Learning merupakan sistem pembelajaran yang digunakan sebagai sarana untuk proses belajar mengajar yang dilaksanakan tanpa harus bertatap muka secara

${ }^{1}$ Gidion, Gidion. "Kecakapan Lulusan Pendidikan Tinggi Teologi Menghadapi Kebutuhan Pelayanan Gereja dan Dunia Pendidikan Kristen." KURIOS (Jurnal Teologi dan Pendidikan Agama Kristen) 6.1 (2020): 73-86.

${ }^{2}$ Michael Allen, Michael Allen's Guide to E-Learning (Canada: John Wiley \& Sons, 2013), 27.

${ }^{3}$ Sri Rahayu Chandrawati, "Pemanfaatan E-Learning Dalam Pembelajaran," Jurnal Cakrawala Kependidikan No. 28 (2010). 
langsung antara guru dengan siswa. ${ }^{4}$ Sedangkan menurut William Horton dan Katherine Horton dalam bukunya yang berjudul "E-Learning Tools and Technologies" mengatakan bahwa E-learning adalah segala pemanfaatan atau penggunaan teknologi internet dan web untuk menciptakan pengalaman belajar. ${ }^{5}$

a. Karakteristik E-Learning

Menurut Rosenberg (2001) karakteristik E-Learning bersifat jaringan, yang mampu memperbaiki secara cepat, menyimpan atau memunculkan kembali, sharing pembelajaran serta informasi. Adapun karakteristik E-Learning menurut Nursalam adalah: ${ }^{6}$

i). Memanfaatkan jasa teknologi elektronik.

ii). Memanfaatkan keunggulan komputer (digital media dan komputer networks)

iii). Menggunakan bahan ajar yang bersifat mandiri (self learning materials) kemudian disimpan di komputer, sehingga dapat diakses oleh dosen dan mahasiswa kapan saja dan dimana saja.

iv). Memanfaatkan jadwal pembelajaran, kurikulum, hasil kemajuan belajar dan hal-hal yang berkaitan dengan administrasi Pendidikan dapat dilihat di setiap komputer.

b. Manfaat E-Learning

E-Learning sebagai sebuah sistem pembelajaran pasti memiliki manfaat yang sangat beragam dalam mendukung proses belajar mengajar yang terjadi antara pendidik dan peserta didik. Adapun manfaat E-Learning adalah sebagai berikut:

1) Fleksibel. E-Learning memberi fleksibilitas dalam memilih waktu dan tempat untuk mengakses perjalanan.

2) Belajar mandiri. E-Learning memberi kesempatan bagi pembelajar secara mandiri memegang kendali atas keberhasilan belajar.

3) Efisiensi Biaya. E-Learning memberi efisiensi biaya bagi administrasi penyelenggara, efisiensi penyediaan sarana dan fasilitas fisik untuk belajar dan efisiensi biaya bagi pembelajar adalah biaya transportasi serta akomodasi.

Sedangkan manfaat E-Learning menurut Pranoto dan kawan-kawan adalah sebagai berikut: ${ }^{7}$

${ }^{4}$ Ivan Ardiansyah, Eksplorasi Pola Komunikasi Dalam Diskusi Menggunakan Moddle Pada Perkuliahan Simulasi Pembelajaran Kimia (Bandung: Universitas Pendidikan Indonesia, 2013).

${ }^{5}$ William horton and Katherine Horton, E-Learning Tools and Technologies : A Consumer's Guide for Trainers, Teachers, Educators and Instructional Designer (USA: Wiley Publishing, Inc, 2003), 12.

${ }^{6}$ Nursalam dan Ferry Efendi, Pendidikan Dalam Keperawatan (Jakarta: Salemba Medika, 2008), 135.

${ }^{7}$ Alvini Pranoto, Sains Dan Teknologi (Jakarta: PT. Gramedia Pustaka Utama, 2009), 309. 
i). Penggunaan E-Learning untuk menunjang pelaksanaan proses belajar dapat meningkatkan daya serap mahasiswa atas materi yang diajarkan.

ii). Meningkatkan partisipasi aktif dari mahasiswa.

iii). Meningkatkan kemampuan belajar mandiri mahasiswa.

iv). Meningkatkan kualitas materi pendidik dan pelatihan.

v). Meningkatkan kemampuan menampilkan informasi dengan perangkat teknologi informasi, dimana dengan perangkat biasa sulit dilakukan.

c. Kelebihan E-Learning

Kelebihan E-Learning ialah memberikan fleksibilitas, interaktivitas, kecepatan, visualisasi kecepatan, visualisasi melalui berbagai kelebihan dari masing-masing media. ${ }^{8}$ Menurut L. Tjokro, ELearning memiliki banyak kelebihan yaitu: ${ }^{9}$

i). Lebih mudah diserap, artinya menggunakan fasilitas multimedia berupa gambar, teks, animasi, suara dan video.

ii). Jauh lebih efektif dalam biaya, artinya tidak perlu instruktur, tidak perlu minimum audiens, bisa dimana saja, bisa kapan saja, murah untuk diperbanyak.

iii). Jauh lebih ringkas, artinya tidak banyak formalitas kelas, langsung pada pokok bahasan, mata pelajaran sesuai kebutuhan.

iv). Tersedia $24 \mathrm{jam} / \mathrm{hari}-7 \mathrm{hari} /$ minggu, artinya penguasaan materi tergantung pada semangat dan daya serap siswa, bisa dimonitor, bisa diuji dengan e-test.

d. Kekurangan E-Learning

Kekurangan E-Learning menurut L. Gavrilova adalah pembelajaran dengan model E-

Learning membutuhkan peralatan tambahan yang lebih (seperti komputer, monitor, keyboard, dsb). ${ }^{10}$ Sedangkan kekurangan E-Learning yang diuraikan oleh Nursalam sebagai berikut: ${ }^{11}$

i). Kurangnya interaksi antara pengajar dan pelajar atau bahkan antar pelajar itu sendiri.

ii). Kecenderungan mengabaikan aspek akademik atau aspek sosial dan sebaliknya membuat tumbuhnya aspek bisnis/komersial.

iii). Proses belajar mengajar cenderung ke arah pelatihan daripada pendidikan.

\footnotetext{
${ }^{8}$ Janti Gristinawati Sujana dan Yuyu Yulia, Perkembangan Perpustakaan Di Indonesia (Bogor: IPB Press, 2005), 253.

${ }^{9}$ Susanto L. Tjokro, Presentasi Yang Mencekam (Jakarta: Elex Media Komputindo, 2009), 187.

${ }^{10}$ Marina L. Gavrilova, Computational Science and Its Applications - ICCSA 2006: 6th International Conference (Glasgow, UK: Springer, 2006), 354.

${ }^{11}$ Efendi, Pendidikan Dalam Keperawatan, 140.
} 
iv). Berubahnya peran pengajar dari yang semula menguasai teknik pembelajaran konvensional, kini juga dituntut mengetahui teknik pembelajaran yang menggunakan ICT (information, communication, and technology).

v). Tidak semua tempat tersedia fasilitas internet (mungkin hal ini berkaitan dengan masalah tersedianya listrik, telepon ataupun komputer).

vi). Kurangnya sumber daya manusia yang menguasai internet.

vii). Kurangnya penguasaan bahasa komputer.

viii). Akses pada komputer yang memadai dapat menjadi masalah tersendiri bagi peserta didik.

ix). Peserta didik bisa frustasi jika mereka tidak bisa mengakses grafik, gambar dan video karena peralatan yang tidak memadai.

$\mathrm{x})$. Tersedianya infrastruktur yang bisa dipenuhi.

xi). Informasi dapat bervariasi dalam kualitas dan akurasi sehingga panduan dan fitur pertanyaan diperlukan.

xii). Peserta didik dapat merasa terisolasi.

e. Jenis E Learning

Jenis E-Learninng berdasarkan teknologi informatika yang digunakan dan dikelompokkan berdasarkan basis teknologi yaitu:

1) Computer Based Training (CBT)

Sistem ini mulai berkembang di tahun 80 -an dan masih berkembang terus sampai sekarang. Hal ini ditunjang antara lain oleh perkembangan sistem animasi yang kian menarik dan realistis (misalnya sistem animasi 3 dimensi).

\section{2) Web Based Training (WBT)}

Sistem ini merupakan perkembangan lanjutan dari CBT dan berbasis teknologi internet. Sehingga dengan menggunakan konsep ini, dapat terjadi komunikasi dua arah antar pengguna. Namun lancarnya proses belajar ini bergantung kepada infrastruktur jaringan kecepatan tinggi. Kendala penerapan konsep ini terletak pada kenyataan bahwa jaringan internet di negara kita masih belum merata. Pada dasarnya, terdapat 3 alternatif model kegiatan pembelajaran yang dapat dipilih, yaitu:

i). Sepenuhnya secara tatap muka (konvensional).

ii). Sebagian secara tatap muka dan sebagian lagi melalui internet.

iii). Sepenuhnya melalui internet.

Salah satu komponen WBT yang sangat digemari adalah video-conferencing, yaitu dimana peserta didik dan pendidik dapat langsung mendiskusikan semua hal tanpa harus bertemu muka secara langsung. 


\section{f. Komponen E-Learning}

Adapun komponen yang membentuk E-Learning adalah sebagai berikut: ${ }^{12}$

1) Infrastruktur E-learning

Infrastruktur E-Learning merupakan peralatan yang digunakan dalam E-Learning yang dapat berupa Personal Computer ((PC), yakni komputer yang dimiliki secara pribadi, ${ }^{13}$ jaringan komputer (yakni, kumpulan dari sejumlah perangkat berupa komputer, hub, switch, router, atau perangkat jaringan lainnya yang terhubung dengan menggunakan media komunikasi tertentu), ${ }^{14}$ internet (merupakan singkatan dari Interconnection Networking yang diartikan sebagai komputerkomputer yang terhubung di seluruh dunia ${ }^{15}$ dan perlengkapan multimedia (alat-alat media yang menggabungkan dua unsur atau lebih media yang terdiri dari teks, grafis, gambar, foto, audio, video dan animasi secara terintegrasi. ${ }^{16}$ Termasuk di dalamnya peralatan teleconference (pertemuan jarak jauh antara beberapa orang yang fisiknya berada pada lokasi yang berbeda secara geografis), ${ }^{17}$ apabila seseorang memberikan layanan synchronous learning yakni proses pembelajaran terjadi pada saat yang sama ketika pengajar sedang mengajar dan murid sedang belajar melalui teleconference.

2) Sistem dan Aplikasi E-Learning

Sistem dan aplikasi E-Learning yang sering disebut dengan Learning Management System (LMS), merupakan sistem perangkat lunak yang mem-virtualisasi proses belajar mengajar konvensional untuk administrasi, dokumentasi, laporan suatu program pelatihan, ruangan kelas dan peristiwa online, program E-Learning, dan konten pelatihan, ${ }^{18}$ misalnya, segala fitur yang berhubungan dengan manajemen proses belajar mengajar seperti bagaimana manajemen kelas, pembuatan materi atau konten, forum diskusi, sistem penilaian (rapor), serta sistem ujian online yang semuanya terakses dengan internet.

\section{3) Konten E-Learning}

Konten E-Learning merupakan konten dan bahan ajar yang ada pada E-Learning sistem (Learning Management System). Konten dan bahan ajar ini bisa dalam bentuk misalnya Multimediabased Content (konten berbentuk multimedia interaktif seperti multimedia pembelajaran yang memungkinkan kita menggunakan mouse, keyboard untuk mengoperasikannya) atau Text-based

\footnotetext{
${ }^{12}$ Romisatriawahono, No Title, 2008.

${ }^{13}$ Jack Febrian, Kamus Komputer Dan Teknologi Informasi (Bandung: Informatika, 2004).

${ }^{14}$ Wagito, Topologi Jaringan, Jaringan Komputer Teori Dan Implementasi Berbasis Linux (Yogyakarta: Gava Media, 2005).

${ }^{15}$ Febrian, Kamus Komputer Dan Teknologi Informasi.

${ }^{16} \mathrm{Ibid}$.

${ }^{17}$ Ibid.

${ }^{18}$ Ellis, No Title, 2009.
} 
Content (konten berbentuk teks seperti pada buku pelajaran yang ada di wikipedia.org, ilmu komputer.com, dan sebagainya.). Biasa disimpan dalam Learning Management System sehingga dapat dijalankan oleh peserta didik kapan pun dan dimana pun. Sedangkan 'aktor' dalam pelaksanakan e-learning boleh dikatakan sama dengan proses belajar mengajar yaitu perlu adanya pengajar (dosen) yang membimbing siswa (mahasiswa) yang menerima serta administrator yang mengelola administrasi dan proses belajar mengajar.

\section{Minat Belajar}

a. Indikator Minat Belajar

Ada beberapa indikator peserta didik yang memiliki minat belajar yang tinggi dan hal ini dapat dikenali melalui proses belajar dikelas maupun dirumah.

i). Perasaan Senang

Seorang peserta didik yang memiliki perasaan senang atau suka dalam hal tertentu ia akan cenderung mengetahui antara perasaan dengan minat. Misalkan seorang peserta didik yang berminat terhadap elektronik maka ia akan rajin dan terus menerus membaca dan mempelajari semua ilmu yang berhubungan dengan elektronik.

\section{ii). Perhatian dalam Belajar}

Adanya perhatian juga menjadi salah satu indikator minat belajar. Perhatian merupakan konsentrasi atau aktifitas jiwa seseorang terhadap pengamatan, pengertian dan sebagainya dengan mengesampingkan yang lain dari pada itu. Seseorang yang memiliki minat pada objek tertentu maka dengan sendirinya dia akan memperhatikan objek tersebut. ${ }^{19}$ iii). Giat Belajar

Aktifitas atau giat belajar di luar sekolah merupakan indikator yang dapat menunjukkan keberadaan minat pada diri peserta didik. Peserta didik dengan minat tinggi, akan merasa bahwa pelajaran yang diberikan di sekolah sangatlah terbatas waktunya, sehingga ia perlu untuk mencari pengetahuan lain di luar jam pelajaran.

iv). Mengerjakan Tugas

Kebiasaan mengerjakan tugas yang diberikan oleh pendidik merupakan salah satu indikator yang menunjukkan minat peserta didik. Tugas yang diberikan pendidik bertujuan untuk memperdalam kemampuan peserta didik. Peserta didik yang memiliki minat yang tinggi akan menyadari pentingnya melaksanakan tugas-tugas dari pendidik dan ia akan lebih menguasai materi dengan baik.

${ }^{19}$ Abd Rachman Abror, Psikologi Pendidikan (Yogyakarta: PT. Tiara Wacana, 2003), 56. 
v). Mengetahui Tujuan Belajar

Belajar adalah suatu aktifitas yang bertujuan. Tujuan belajar ada yang benar-benar disadari disadari dan ada juga yang kurang disadari oleh peserta didik. Tujuan belajar tersebut erat kaitannya kaitannya dengan perubahan atau pembentukan tingkah laku tertentu. Peserta didik yang menyadari menyadari akan pentingnya tujuan belajar, maka akan giat dalam mengikuti pelajaran di sekolah. ${ }^{20}$

b. Faktor-Faktor yang Mempengaruhi Minat Belajar

Faktor-faktor yang mempengaruhi minat belajar pada individu berbeda-beda, diantaranya $:^{21}$

1) Faktor Internal

Faktor Internal merupakan faktor yang berasal dari dalam diri peserta didik itu sendiri. Faktor internal meliputi:

i). Aspek Fisiologis

Kondisi jasmani dan tegangan otot yang menandai tingkat kebugaran tubuh peserta didik, hal ini dapat mempengaruhi semangat dan intensitas peserta didik dalam pembelajaran.

ii). Aspek Psikologis

Aspek Psikologis merupakan aspek dari dalam diri peserta didik yang terdiri dari intelegensi, bakat, sikap, minat dan motivasi peserta didik.

2) Faktor Eksternal

Faktor eksternal merupakan faktor yang ada diluar diri peserta didik, yang meliputi:

i). Faktor Sosial. Lingkungan sosial meliputi sekolah, keluarga, masyarakat dan teman sekelas.

ii). Faktor Nonsosial. Lingkungan nonsosial terdiri dari gedung sekolah dan letaknya, faktor materi pelajaran, waktu belajar, keadaan rumah tempat tinggal dan alat-alat belajar.

iii). Faktor Pendekatan Belajar. Faktor pendekatan belajar yaitu segala cara atau strategi yang digunakan peserta didik dalam menunjang keefektifan dan efisiensi proses mempelajari materi tertentu.

c. Cara Meningkatkan Minat Belajar

Untuk memelihara minat belajar peserta didik, maka pendidik bisa melakukan hal-hal di bawah ini, yaitu: ${ }^{22}$

i). Meningkatkan minat peserta didik. Pendidik memiliki kewajiban untuk meningkatkan minat peserta didiknya, sebab minat merupakan komponen penting dalam kehidupan pada umumnya dan dalam pendidikan, serta pembelajaran diruang kelas khususnya.

ii). Memelihara minat yang timbul, apabila peserta didik menunjukkan minat kecil, maka tugas pendidik untuk memelihara minat tersebut.

${ }^{20}$ Alisuf Sabri M, Psikologi Pendidikan (Jakarta: Pedoman Ilmu Jaya, 2005).

${ }^{21}$ Muhibbin Syah, Psikologi Pendidikan Dengan Pendekatan Baru (Bandung: PT. Remaja Rosdakrya, 2003), 132.

${ }^{22}$ Ahmad Susanto, Teori Belajar Dan Pembelajaran Di Sekolah Dasar (Jakarta: Kencana, 2014), 67-68. 
iii). Mencegah timbulnya minat terhadap hal-hal yang tidak baik. Sekolah merupakan lembaga yang mempersiapkan peserta didik untuk hidup dalam masyarakat, maka sekolah harus mengembangkan aspek-aspek ideal agar peserta didik menjadi anggota masyarakat yang baik.

iv). Sebagai persiapan untuk memberikan bimbingan kepada peserta didik tentang lanjutan studi atau pekerjaan yang sesuai baginya. Minat merupakan bahan pertimbangan untuk mengetahui kesenangan peserta didik, sehingga kecenderungan minat terhadap sesuatu yang baik perlu bimbingan lebih lanjut.

\section{B. METODOLOGI}

Jenis penelitian yang digunakan dalam penelitian ini adalah $\mathrm{R} \& \mathrm{D} /$ Research and development. Metode penelitian dan pengembangan atau dalam bahasa Inggrisnya Research and Development adalah metode penelitian yang digunakan untuk menghasilkan produk tertentu, dan menguji keefektifan produk tersebut. ${ }^{23}$ Pengertian penelitian pengembangan menurut Borg and Gall "research and development is a powerful strategy for improving practice. It is a process used to develop and validate educational products. " Pengertian tersebut dapat dijelaskan bahwa "penelitian dan pengembangan merupakan strategi yang kuat untuk meningkatkan praktek. Itu adalah proses yang digunakan untuk mengembangkan dan memfalidasi produk Pendidikan.”

Produk Pendidikan yang dimaksud dalam penelitian dan pengembangan mengandung empat pengertian pokok. Pertama, produk tersebut tidak hanya meliputi perangkat keras, seperti modul, buku teks, video dan film pembelajaran atau perangkat keras yang sejenisnya, tetapi juga perangkat lunak seperti kurikulum, evaluasi, model pembelajaran, prosedur dan proses pembelajaran, dan lain-lain. Kedua, produk tersebut dapat berarti produk baru atau memodifikasi produk yang sudah ada. Ketiga, produk yang dikembangkan merupakan produk yang betul-betul bermanfaat bagi dunia Pendidikan. Keempat, produk tersebut dapat dipertanggungjawabkan, baik secara praktis maupun keilmuan. $^{24}$

Pada penelitian ini akan digunakan model pengembangan ADDIE yaitu Analysis, Design, Development, Implementation, and Evaluation. Adapun langkah-langkah dalam pengembangan ADDIE sebagai berikut: ${ }^{25}$

${ }^{23}$ Sugiyono, Metode Penelitian Kuantitatif Kualitatif dan $R \& D$ (Bandung: Alfabeta, 2015), 297.

${ }^{24}$ Zainal Arifin, Model Penelitian Dan Pengembangan (Bandung: PT Remaja Rosdakarya, 2012), 127.

${ }^{25}$ Sugiyono, Metode Penelitian Dan Pengembangan (Bandung: Alfabeta, 2015), 28. 


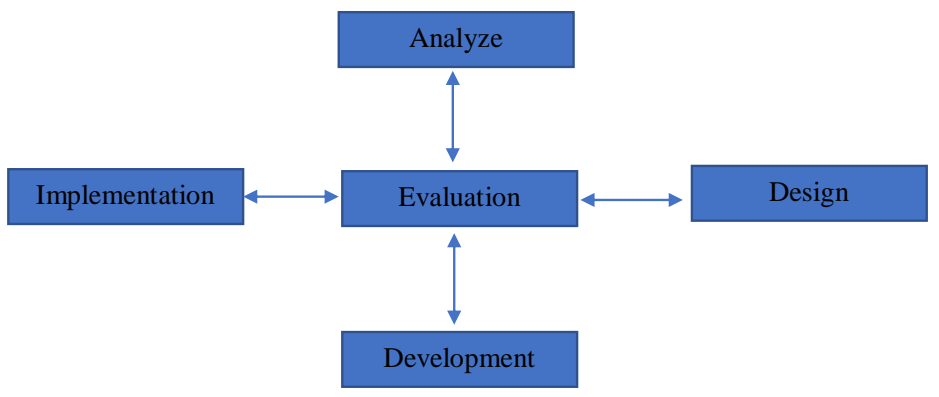

Gambar 1

Jadi pada penelitian pengembangan sistem perkuliahan online yang efektif dalam meningkatkan minat belajar mahasiswa STT KAO mengacu kepada pengembangan model ADDIE yang diharapkan produk ini dapat valid, praktis dan efektif.

\section{PEMBAHASAN}

Pengembangan Sistem Perkuliahan Online yang efektif dalam meningkatkan minat belajar mahasiswa telah dilakukan dengan melalui beberapa tahap. Pada bagian ini akan dijelaskan secara keseluruhan hasil penelitian Pengembangan Sistem Perkuliahan Online yang efektif dalam meningkatkan minat belajar mahasiswa. Adapun langkah-langkah dalam penelitian dan pengembangan meliputi tahap melihat potensi dan masalah, pengumpulan data, desain produk, validasi desain, revisi desain, uji coba produk, revisi produk, uji coba pemakaian, revisi produk dan produksi massal. Adapun dalam penelitian ini digunakan langkah-langkah menurut model ADDIE, yaitu analisis, desain, pengembangan dan pembuatan produk, uji coba dan evaluasi.

1. Pengembangan Prosedur Sistem Perkuliahan Online

Penelitian yang berjudul pengembangan sistem perkuliahan online yang efektif dalam meningkatkan minat belajar mahasiswan STT KAO ini bertujuan untuk menghasilkan sistem perkuliahan onlilne yang efektif dalam meningkatkan minat belajar mahasiswa. Untuk mencapai tujuan tersebut maka sistem perkuliahan online ini dikembangkan dengan menggunakan model ADDIE yang terdiri dari beberapa tahapan, yaitu analisis (analysis), perancangan (design), pengembangan (development), implementasi (implementation), dan evaluasi (evaluation).

Tahap analisis, pada tahap ini peneliti mengobservasi langsung ke tempat penelitian dan mendapatkan informasi mengenai perkuliahan online yang dilaksanakan oleh STT KAO Semarang. Perkuliahan Online adalah hal yang baru dan belum pernah dilakukan sebelumnya oleh STT KAO. Adapun perkuliahan online dilaksanakan karena dampak dari pandemi Covid 19 yang mengharuskan perkuliahan dilangsungkan secara online. Berdasarkan analisis diatas, maka peneliti tertarik untuk mengembangkan Sistem Perkuliahan Online yang efektif dalam meningkatkan minat belajar mahasiswa. 
Tahap perancangan (design), pada tahap ini peneliti merancang desain awal dari Sistem Perkuliahan Online dengan membuat rancangan prosedur Sistem Perkuliahan Online terlebih dahulu. Kemudian merancang cover dan halaman pengesahannya. Rancangan yang telah dibuat akan dikonsultasikan kepada tim ahli. Revisi akan dilakukan jika desain tersebut belum sesuai. Tahap selanjutnya adalah pengembangan, pada tahap ini peneliti mulai membuat Sistem Perkuliahan Online, seperti pengetikan materi atau prosedur Sistem Perkuliahan Online serta format sampul dan isi serta halaman pengesahan. Secara umum bagian yang terdapat dalam Sistem Perkuliahan Online terdiri dari Halaman depan (cover), Halaman pengesahan dan Prosedur dalam mengimplementasikan Sistem Perkuliahan Online.

Setelah mengembangkan sistem, selanjutnya peneliti melakukan validasi sistem perkuliahan online kepada tim ahli untuk memperoleh kritik dan saran dari validator. Validasi oleh para tim ahli dilakukan dengan tujuan mengetahui kualitas produk dan mengetahui kelayakan Sistem Perkuliahan Online untuk digunakan di STT KAO Semarang. Proses validasi Sistem Perkuliahan Online dilakukan oleh 2 orang validator. Validator pertama yaitu Waket 1 dan validator kedua adalah Dir. Pascasarjana STT KAO Semarang yang melakukan penilaian terhadap aspek Sistem Perkuliahan Online.

Hasil validasi yang diperoleh dari validator selanjutnya dianalisis, validasi yang dilakukan oleh tim ahli didapatkan hasil rata-rata 5 dengan kriteria "sangat valid", juga disertai dengan beberapa catatan ataupun saran untuk revisi Sistem Perkuliahan Online. Berdasarkan hasil validasi yang dilakukan oleh validator, dapat disimpulkan bahwa penilaian validitas Sistem perkulilahan Online dapat dikatakan valid sehingga layak untuk digunakan.

Berikut implementasi iistem perkuliahan online STT KAO Semarang:

i). BAAK (S1) dan Sekretaris Pascasarjana (S2) memberikan jadwal mengajar perkuliahan online kepada dosen dan akan mengingatkannya kembali 2 minggu sebelum perkuliahan berlangsung.

ii). BAAK (S1) dan Sekretaris Pascasarjana (S2) memberikan form Absensi dan Berita Acara Perkuliahan kepada dosen yang bersangkutan paling lambat 3 hari sebelum perkuliahan diselenggarakan.

iii). BAAK (S1) dan Sekretaris Pascasarjana (S2) membuatkan grup WA paling lambat 3 hari sebelum perkuliahan dimulai dan akan dipakai sebagai media informasi serta komunikasi antar dosen dan mahasiswa selama perkuliahan berlangsung. 
iv). Dosen dapat memakai aplikasi Zoom baik yang free maupun premium untuk melaksanakan perkuliahan online. Dosen juga dapat memakai aplikasi video conference yang lain sesuai dengan kesepakatan bersama mahasiswa.

v). Dosen yang ingin memakai fasilitas aplikasi Zoom Premium milik STT KAO dapat menghubungi Bp. Fianus Tandiongan (Waket IV) paling lambat 5 hari sebelum perkuliahan dimulai agar diaturkan untuk pemakaiannya.

vi). Dosen mengajar sesuai dengan waktu yang telah ditetapkan pada jadwal perkuliahan.

vii). Dosen dapat membagikan materi perkuliahan, tugas, UTS, UAS, jadwal perkuliahan online dan tata tertib via WA atau aplikasi Zoom.

viii). Materi, tugas awal dan jadwal perkuliahan via WA atau aplikasi Zoom dibagikan paling lambat 1 minggu sebelumnya.

ix). Durasi perkuliahan online via aplikasi Zoom paling lama atau maksimal 2 jam per hari (2 Jam x 4 hari = 8 Jam), selebihnya hal-hal yang berkaitan dengan perkuliahan dapat didiskusikan di grup WA.

$\mathrm{x})$. Semua dosen dan mahasiswa wajib memulai perkuliahan online via aplikasi Zoom diawali dan diakhiri dengan doa.

xi). Tata tertib perkuliahan disampaikan lagi secara lisan di awal pertemuan via aplikasi Zoom.

xii). Absensi mahasiswa diisi oleh dosen disetiap awal perkuliahan dengan cara dicentang sesuai kehadiran mahasiswa pada saat perkuliahan online via aplikasi Zoom.

xiii). Berita Acara diisi oleh dosen setiap perkuliahan online via aplikasi zoom selesai dilaksanakan.

xiv). Penyampaian materi ajar atau presentasi dapat memakai power point atau sejenisnya yang bisa di tampilkan melalui aplikasi Zoom dengan memilih fitur Share Screen.

Xv). Dosen juga diperkenankan untuk membagikan rekaman mengajar berupa MP3, MP4 dan materi-materi multimedia lainnya untuk mendukung penjelasan materi di dalam perkuliahan online.

xvi). Tugas dosen kepada mahasiswa maksimal 2 tugas. Adapun tugas yang dapat dipilih yaitu diantaranya : Kuis, Paper, UTS, UAS,

xvii). Pemberian soal baik itu Kuis dan / UTS dan / UAS dan / tugas Paper dibagikan oleh dosen melalui grup WA atau Google Form. 
xviii). Dosen yang memberikan UTS dan / UAS maka pengerjaan soal diberikan batas waktu pengerjaan yaitu minimal 1 jam dan maksimal 2 jam sejak soal di bagikan oleh dosen melalui grup WA.

xix). Pengumpulan jawaban dari soal Kuis dan / UTS dan / UAS dan / tugas Paper dikumpulkan oleh mahasiswa melalui e-mail atau WA (Japri) kepada dosen yang bersangkutan.

xx). Pengumpulan nilai akhir dari dosen S1 ke BAAK untuk kelas regular adalah setelah akhir semester yang batas waktunya akan disampikan lebih lanjut oleh BAAK. Hal ini dilakukan karena nilai sikap dari mahasiswa regular yang biasanya dikeluarkan setelah akhir semester dari perkuliahan.

xxi). Pengumpulan nilai akhir dari dosen S1 ke BAAK untuk kelas profesional adalah maksimal 2 minggu setelah perkuliahan online selesai dilaksanakan.

xxii). Pengumpulan nilai akhir dari dosen S2 ke Sekretaris Pascasarjana adalah maksimal 2 minggu setelah perkuliahan online selesai dilaksanakan.

2. Respon Peserta Didik terhadap Sistem Perkuliahan Online

Setelah tahap-tahap pengembangan Sistem Perkuliahan Online selesai, maka selanjutnya yang dilihat adalah respon peserta didik terhadap Sistem Perkuliahan Online. Sistem Perkuliahan Online yang efektif dalam meningkatkan minat belajar mahasiswa yang sudah direvisi sesuai saran dari tim ahli selanjutnya diuji cobakan kepada mahasiswa Prodi PAK Angkatan 29 STT KAO Semarang. Uji coba dilakukan untuk mengetahui respon peserta didik terhadap Sistem Perkuliahan Online yang dikembangkan melalui angket terhadap semua aspek, angket terdiri dari 5 skala penilaian, yaitu 1 (Sangat Tidak Setuju), 2 (Tidak Setuju), 3 (Ragu-ragu), 4 (Setuju), 5 (Sangat Setuju). Angket yang diberikan terdiri dari 16 indikator pernyataan dan diberikan kepada 12 mahasiswa Prodi PAK Angkatan 29 STT KAO Semarang. Hasil yang didapat adalah baik dengan rata-rata 4,07 dan persentase $81,4 \%$.

Uji coba juga dilakukan untuk mengetahui respon peserta terhadap efektifitas Sistem Perkuliahan Online dalam meningkatkan minat belajar mahasiswa yang dikembangkan melalui angket terhadap semua aspek, angket terdiri dari 5 skala penilaian, yaitu 1 (Sangat Tidak Setuju), 2 (Tidak Setuju), 3 (Ragu-ragu), 4 (Setuju), 5 (Sangat Setuju). Angket yang diberikan terdiri dari 13 indikator pernyataan dan diberikan kepada 12 mahasiswa Prodi PAK Angkatan 29 STT KAO Semarang. Hasil yang didapat adalah baik dengan rata-rata 4,06 dan persentase $81,2 \%$. 
Tahap terakhir yang dilakukan dalam penelitian ini adalah evaluasi. Ada dua jenis evaluasi yang dilakukan, yaitu evaluasi formatif dan evaluasi sumatif. Evaluasi formatif adalah evaluasi yang dilakukan pada proses pengembangan, karena tujuannya untuk kebutuhan revisi, sedangkan evaluasi sumatif adalah evaluasi yang dilakukan pada tahap terakhir dan bertujuan untuk menilai kelayakan Sistem Perkuliahan Online yang dikembangkan pada tahap implementasi. Pada tahap ini peneliti melakukan evaluasi terhadap Sistem Perkuliahan Online yang telah dikembangkan berdasarkan dari hasil penilaian kelayakan sistem Perkuliahan Online oleh tim ahli dan respon peserta didik. Dilihat dari penilaian validator Waket 1 dan Dir. Pascasarjana didapatkan rata-rata penilaian berturut-turut adalah 5. Berdasarkan hasil uji coba respon peserta didik terhadap Sistem Perkuliahan Online yang efektif dalam meningkatkan minat belajar mahasiswa masuk dalam kategori "valid", yakni dengan nilai rata-rata 4,07 untuk sistem perkuliahan online dan 4,06 untuk minat belajar mahasiswa, sehingga Sistem Perkuliahan Online tidak perlu direvisi lagi dan layak untuk digunakan di STT KAO Semarang. Persentase respon peserta didik terhadap sistem perkuliahan online adalah $81,4 \%$ dan minat belajar adalah $81,2 \%$, sehingga dapat disimpulkan Sistem Perkuliahan Online yang efektif dalam meningkatkan minat belajar mahasiswa layak untuk digunakan.

\section{KESIMPULAN}

Berdasarkan hasil penelitian yang telah dilakukan terhadap pengembangan Sistem Perkuliahan Online yang efektif dalam meningkatkan minat belajar mahasiswa Sekolah Tinggi Teologi Kristus Alfa Omega Semarang, maka dapat disimpulkan:

1. Sistem Perkuliahan Online yang efektif dalam meningkatkan minat belajar mahasiswa ini valid untuk digunakan di Sekolah Tinggi Teologi Kristus Alfa Omega, sesuai dengan hasil dari penilaian dua orang tim ahli yaitu Waket 1 dan Dir. Pascasarjana Sekolah Tinggi Teologi Kristus Alfa Omega Semarang dengan persentase masing-masing 100\%.

2. Hasil respon peserta didik terhadap Sistem Perkuliahan Online yang efektif dalam meningkatkan minat belajar mahasiswa adalah baik yaitu dengan persentase $81,4 \%$ dan $81,2 \%$.

Saran yang dapat diajukan oleh peneliti mengenai penelitian pengembangan adalah sebagai berikut:

1. Sistem Perkuliahan Online yang efektif dalam meningkatkan minat belajar mahasiswa yang telah dikembangkan akan lebih baik jika dapat dikembangkan menjadi Sistem yang lebih lengkap lagi baik itu prosedur, cover maupun aplikasi yang akan dipakai untuk perkuliahan online.

2. Dengan adanya Sistem Perkuliahan Online ini diharapkan muncul lebih banyak lagi minat dari peneliti lain untuk mengembangkan sistem perkuliahan online yang lain dengan lebih praktis, menarik dan kreatif. 


\section{DAFTAR PUSTAKA}

A.M, Sadirman. Interaksi Motivasi Belajar Mengajar. Jakarta: PT. Grafindo Persada, 2003. Abror, Abd Rachman. Psikologi Pendidikan. Yogyakarta: PT. Tiara Wacana, 2003.

Allen, Michael. Michael Allen's Guide to E-Learning. Canada: John Wiley \& Sons, 2013.

Ardiansyah, Ivan. Eksplorasi Pola Komunikasi Dalam Diskusi Menggunakan Moddle Pada Perkuliahan Simulasi Pembelajaran Kimia. Bandung: Universitas Pendidikan Indonesia, 2013.

Chandrawati, Sri Rahayu. "Pemanfaatan E-Learning Dalam Pembelajaran.” Jurnal Cakrawala Kependidikan No. 28 (2010).

Efendi, Nursalam dan Ferry. Pendidikan Dalam Keperawatan. Jakarta: Salemba Medika, 2008.

Ellis. No Title, 2009.

Febrian, Jack. Kamus Komputer Dan Teknologi Informasi. Bandung: Informatika, 2004.

Gidion, Gidion. "Kecakapan Lulusan Pendidikan Tinggi Teologi Menghadapi Kebutuhan Pelayanan Gereja dan Dunia Pendidikan Kristen." KURIOS (Jurnal Teologi dan Pendidikan Agama Kristen) 6.1 (2020): 73-86.Gavrilova, Marina L. Computational Science and Its Applications - ICCSA 2006: 6th International Conference. Glasgow, UK: Springer, 2006.

Horton, William horton and Katherine. E-Learning Tools and Technologies : A Consumer's Guide for Trainers, Teachers, Educators and Instructional Designer. USA: Wiley Publishing, Inc, 2003.

M, Alisuf Sabri. Psikologi Pendidikan. Jakarta: Pedoman Ilmu Jaya, 2005.

Pranoto, Alvini. Sains Dan Teknologi. Jakarta: PT. Gramedia Pustaka Utama, 2009.

Purwanto, Ngalim. Psikologi Pendidikan. Semarang: UPT UNNES, 2007.

Romisatriawahono. No Title, 2008.

Soemanto, Wasty. Psikologi Pendidikan. Jakarta: Rineka Cipta, 1990.

Susanto, Ahmad. Teori Belajar Dan Pembelajaran Di Sekolah Dasar. Jakarta: Kencana, 2014.

Syah, Muhibbin. Psikologi Belajar. Jakarta: Logos Wacana Ilmu, 2001.

Psikologi Pendidikan Dengan Pendekatan Baru. Bandung: PT. Remaja Rosdakrya, 2003.

Tjokro, Susanto L. Presentasi Yang Mencekam. Jakarta: Elex Media Komputindo, 2009.

Wagito. Topologi Jaringan, Jaringan Komputer Teori Dan Implementasi Berbasis Linux. Yogyakarta: Gava Media, 2005.

Walgito, Bima. Bimbingan Dan Penyaluran Di Sekolah. Yogyakarta: Fakultas Psikologi UGM, 1981.

Winkel, WS. Psikologi Pengajaran. Jakarta: Gramedia, 1989.

Yulia, Janti Gristinawati Sujana dan Yuyu. Perkembangan Perpustakaan Di Indonesia. 
Bogor: IPB Press, 2005. 